\title{
SALT TOLERANCE (STO), A STRESS-RELATED PROTEIN IN ARABIDOPSIS HAS A MAJOR ROLE UNDER OTHER STRESS CONDITIONS
}

EI - Shami , M. I. 1; M. M. EI - Danasory ${ }^{2}$; E. F. EI - Hashash ${ }^{1}$; E. I. Zaazaa'; M. A. Hager ${ }^{1}$; S. El kafafi ${ }^{3}$ and M. Elmalky ${ }^{4}$

(1)Agronomy Department, Faculty of Agriculture, Al-Azhar University, Nasr city, Cairo, Egypt

(2)Biochemistry Department Faculty of Agriculture, Al-Azhar University, Nasr city, Cairo, Egypt

(3)Botany Department Faculty of Agriculture, Al-Azhar University, Nasr city, Cairo, Egypt

(4)Agricultural Research Centre, Rice Research and Training Centre (RRTC), Sakha, Kafr El-Sheikh, Egypt

\begin{abstract}
Recently, salt tolerance protein (STO) of Arabidopsis and rice were identified and confirmed by STO in yeast cell. Here, we present data of one STO family in Arabidopsis which protein was cloned, and the expression levels of the genes were analysed by Reverse transcriptase (RT)-PCR, using gene-specific primers. We examined the expression of AtSTO mRNA under different stress conditions. The whole plants in age two weeks were treated by $\left(1 \mathrm{mM} \mathrm{H}_{2} \mathrm{O}_{2}\right), \mathrm{NaCl} 0,100,200,400$ $\mathrm{mM}$ of $\mathrm{NaCl}$ concentration and $20 \%$ for $\mathrm{PEG}$ and were incubated for different time. For Brefeldin A (BFA) treatments, were added to the Arabidopsis cells culture in three days growth at concentration of $10 \mathrm{mg} / \mathrm{ml}$, and the samples were collected at different times from added BFA. we present data of one STO family in Arabidopsis which has Zinc-finger protein, and our result indicted that $\mathrm{H}_{2} \mathrm{O}_{2}$, BFA were inhibitor of the activity of AtSTO mRNA and $\mathrm{H}_{2} \mathrm{O}_{2}$ decrease the expression level of AtSTO mRNA. Generally the expression of STO in presence of different concentrations of $\mathrm{NaCl}$ and other stresses factors showed that STO protein play a major role to drought tolerance.

Keywords: Zinc-finger protein /gene structure/ gene expression/ Salt and tolerance/ Arabidopsis/Abbreviations: PEG (polyethylene glycol)
\end{abstract}

\section{INTRODUCTION}

Soil salinity is a major abiotic stress in plant agriculture worldwide, genomic approaches are beginning to revolutionize our understanding of plant tolerance to high salinity and drought. Progress now anticipated through comparative genomics studies of an evolution divers from model organisms and through use of techniques such as high-throughput analysis of expressed sequence tags, large scale parallel analysis of gene expression, targeted or random mutagenesis and gain of function or mutant complementation. The discovery of novel genes determination of their expression patterns in response to abiotic stress and an improved understanding in stress adaptation will provide the basis effective engineering leading to greater stress tolerance (Cushman and Bohnert, 2000). Salt tolerance protein (STO) is a B-box type Zinc-finger protein with sequence similarities to constants, which are required to maintain the folded structure of zinc-finger peptides (Putterill et al., 1995; Lagercrantz and Axelsson, 2000; Griffiths et al., 2003). Many zinc-finger proteins are known to be involved in transcriptional regulation and developmental control. The first identification of (STO) protein 
was through a screening approach using a yeast calcineurin mutant. Thus, yeast null mutants in the catalytic subunit genes (cna1cna2), or in the regulatory subunit gene (cnb1), present a salt sensitive phenotype that can be rescued with STO (Lippuner et al., 1996). Surprisingly, in Arabidopsis plants, STO has been shown that overexpression enhances root growth tolerance to high salinity. In addition, STO interacts with CEO1/RCD1, an Arabidopsis protein that complements an oxidative stress-sensitive yeast strain (Belles-Boix et al., 2000) and negatively regulates a wide range of stress-related downstream genes (Fujibe et al., 2004). CEO1/RCD1 has been recently identified as a new component in the plant salt-stress response, through the interaction with SOS1 (Katiyar-Agarwal et al., 2006). However, an interaction of STO with CONSTITUTIVE PHOTOMORPHOGENESIS 1 (COP1), a negative regulator of photomorphogenesis in the dark, has also been reported (Holm et al., 2001 and Ma et al., 2002).

On the other hand, rice has been become a good model plant for genome research of cereals and for isolation of agronomically important genes, owing to its relatively small genome size $(430 \mathrm{Mb})$. In the Rice Genome Research Program (RGP), they have conducted large-scale sequencing of cDNAs randomly selected from various kinds of libraries with the aim of cataloguing all expressed rice genes, they described and isolated seven kinds of cDNAs that show similarities to the Arabidopsis flowering time gene $\mathrm{CO}$ and salttolerance gene STO (Jianyu SONG et al., 1998).

In the present study, we analysed the structure and transcription level of AtSTO, an AtSTO was analysed has been isolated and characterized and the transcription level of AtSTO under different stress condition such as $\mathrm{H}_{2} \mathrm{O}_{2}$, $\mathrm{BFA}, \mathrm{NaCl}$ and PEG were analysed by RT-PCR.

\section{Plant material}

\section{MATERIALS AND METHODS}

Arabidopsis thaliana (L.) Heynh., Brassicaceae ecotype Colombia was used for all experiments. Wild type seeds were sown on half MS medium, $0.7 \%$ agar plates containing $50 \square \mathrm{g} / \mathrm{ml}$ carbenicillin (Sigma) and grown in $16 \mathrm{~h}$ light, $8 \mathrm{~h}$ dark at $18 \mathrm{C}$. The seeds were sown in pots containing a 3:1 compost: sand mixture and grown in a Sanyo growth chamber at $24 \mathrm{C}$ with 9h light and 15h dark.

\section{Cloning of Arabidopsis STO}

A homology search BlastP in Arabidopsis DNA database using Zincbinding domain was identified a potential accession number 024174 in BAC number T21E18, locus in chromosome 1. The RT-PCR was carried out using the GATEWAY system(Invitrogene). The construction was affected with RNA from root ofatwo weeks seeding old with two primers; sense primers attB1STO (5' GGGG ACA AGT TTG TAG TAC AAA AAA GCA GGC T ATG GCT TAC GCA ACA ACA GCA'3) and anti sense primers attB2-STO (5'GGGGACCACTTTGTA CAACAAGAA AGC TGG GTC ATA CAA TAC AGT GCA CAA AC'3). The PCR products flanked by attB1 and attB2 sequences directionally recombined in vitro at attP1 and attP2 sites contained in the plasmid (pDoner- 207) when incubated with BP clones enzyme. This 
reaction mixture was incubated $1 \mathrm{~h}$ at $25 \mathrm{C}$ and transformed into E.coli $\mathrm{DH} 5 \square$. After select gentamycin $12 \square \mathrm{g} / \mathrm{ml}$, only recombinants can grow because the CCDB gene, contained in the plasmid is lethal, the inserts containing clones were verified by restriction enzymes digestion and by sequencing the full length of STO.

\section{RNA preparation and RT-PCR}

Total RNAs during this work was isolated from Arabidopsis as previously described by (Ausubel et al 1998). RT-PCR was carried out by use ReverseiT one step Kit from Abgene following by the manufacture's instructions with equal amounts of RNA from various samples.

\section{Plant treatments with stresses}

For $\mathrm{H}_{2} \mathrm{O}_{2}$ the whole plants at the age of two weeks were treated by spraying Arabidopsis plant with $\mathrm{H}_{2} \mathrm{O}_{2} 1 \mathrm{mM}$ in $0.95 \% \mathrm{Nacl}, 10 \mathrm{mM}$ Tris- $\mathrm{Hcl} \mathrm{pH}$ 7.5) and incubated for 15,30 , and 60 minutes after application. For BFA treatments, the BFA were added to the Arabidopsis cell culture after three days growth at concentration of $10 \mathrm{mg} / \mathrm{ml}$, and the samples were collected at: $0,30,60,120,180$, and 240 , minutes after addition of BFA. For $\mathrm{NaCl}$ and PEG treatments, $\mathrm{NaCl}$ or PEG was added to the Arabidopsis whole plants in age two weeks in the presence in present of $0,100,200,400 \mathrm{mM} \mathrm{NaCl}$ concentration and $20 \%$ for PEG in half MS medium then incubated for four hours.

\section{Isolation and characterization of AtSTO}

\section{RESULTS AND DISCUSSION}

The zinc finger domain of the Arabidopsis flowering time controller protein CONSTANS (CO)was used following Putterill et al., (1995), to search by the BLAST in plant database (GeneBank), Three Arabidopsis clones (CO, STO, and COL2), seven rice were identified, (SONG et al., 1998) and many other plants clones such as Glycine max, Zea mays and Solanum sogarandinum which have been hypothesized to represent the zinc-finger.To clone AtSTO a reverse transcriptase (RT)-PCR was used. Total RNA was extracted from root in age two weeks and reverse transcriptase was affected to amplify AtSTO with AtSTO gene-specific primers. A comparison of the protein sequence with its homologues in proteins Oryza sativa (OSSTO), Glycine max (GMSTO), Solanum sogarandinum (SSSTO) and Zea mays (ZMSTO), showed that ATSTO clone encode a 27.6 KDa hydrophilic protein of 249 amino acids (Fig1). The analysis of these predicted protein sequences revealed that two cysteine cores in each finger were interrupted by 23 or 24 amino acid residues with a consensus sequence of "Cys-X2-Cys-X8-Cys-X2Cys. It has been reported that the zinc-finger domain of GATA-1 transcription factors are in a "Cys-X2-Cys-xi7-Cys-X2-Cys"arrangement. The amino acid sequences of STO also had significant similarity within their C-terminal basic regions. The basic region could be a functional region related to floweringtime and salt tolerance and it is thought to be mediate protein-protein interactions with GATA transcription factors. The GATA factors DNA binding domain is a class IV zinc finger motif in the form CX2CX17-20CX2C followed by a basic region. In plants, GATA DNA motifs have been implicated in lightdependent and nitrate-dependent control of transcription (teakle et al., 2002). 
Expression profile of the AtSTO gene under $\mathrm{H}_{2} \mathrm{O}_{2}$

Oxidative stress is arising from an imbalance in the generation and removal of reactive oxygen species (ROS). ROS, especially hydrogen peroxide $\left(\mathrm{H}_{2} \mathrm{O}_{2}\right)$, have been associated with a decrease in the activity of different pathways in the plant (Xing et al., 2007). Reactive oxygen species (ROS) has long been known to be deleterious to cellular activities, but their transient increase in cells has increasingly been suggested to act as signals and to mediate the regulation of various cellular activities, such as responses to biotic or abiotic stresses, cell death, stomatal movement, and root hair development (Adler et al., 1995, 1999; Mount, 1996; Kamata and Hirata, 1999; Rhee, 1999; Guan et al., 2000). Among different ROS, only hydrogen peroxide $\left(\mathrm{H}_{2} \mathrm{O}_{2}\right)$ can cross plant membranes and it has been increasingly proved to be one of the most important signals in plant cell signalling, especially in elicitor-induced defence responses (Neill et al., 2002). The obtained results indicated that $\mathrm{H}_{2} \mathrm{O}_{2}$ function as a signalling molecule in plants (Desikan et al; 2001). Regarding the expression of AtSTO mRNA in presence of $\left(1 \mathrm{mM} \mathrm{H} \mathrm{H}_{2}\right)$, the whole plants were treated by spraying Arabidopsis plant and incubated for $0,15,30$, and 60 minutes after spraying. Reverse transcriptase (RT)-PCR was analysed (Fig2). A constant level of loading control (rRNA) was observed in presence of $\mathrm{H}_{2} \mathrm{O}_{2}$ and $(0)$ control (without $\mathrm{H}_{2} \mathrm{O}_{2}$ ). The same expression pattern was observed with short time (15 minutes) of incubation in presence of $\mathrm{H}_{2} \mathrm{O}_{2}$. Whereas, different expression profiles were observed at long time of incubation in presence of $\mathrm{H}_{2} \mathrm{O}_{2}(30$ and 60 minutes). This result indicated that $\mathrm{H}_{2} \mathrm{O}_{2}$ is an inhibitor of the activity of AtSTO mRNA and $\mathrm{H}_{2} \mathrm{O}_{2}$ decrease the expression level of AtSTO mRNA.

\section{Is $A t S T O$ induce by brefeldin A (BFA)?}

BFA is a vesicle transport inhibitor that specifically blocks cell exocytosis but allows endocytosis, resulting in the internalization and accumulation of recycling plasma membrane proteins in BFA compartments (Nebenfuhr et al., 2002). Many plasma membrane proteins, including PIN1, plasma membrane H-ATPase (Geldner et al., 2001, 2003), and PIN2 (Geldner et al., 2003) have been found in BFA compartments. BFA inhibits not only vesicle trafficking but also root and hypocotyl elongation, lateral root formation, and gravitropism of roots and hypocotyls (Geldner et al., 2001, 2003). Regarding the expression of AtSTO mRNA in presence of BFA using Arabidopsis cells culture (Figure $3)$. The cells were treated with Brefeldin $A(B F A)$ and the sample were taken at different periods $(0,30,60,120,180$, and 240 minutes) from adding BFA. Reverse transcriptase (RT)-PCR was analysed (Fig.3), a constant level of loading control (rRNA) was observed in presence of Brefeldin A and (0) control (without BFA). A marked increase of expression level of AtSTO mRNA was observed in response for added BFA after 30 and 60 minutes reaching about two to three folds compared with nontreated cells. Whereas, different expression profiles were observed at long time of incubation in presence of BFA (120, 180 and 240 minutes). This result indicated that BFA is an inhibitor of the activity of AtSTO mRNA.

\section{Expression of AtSTO in NaCl-treated plants.}

Because the AtSTO (cDNA) conferred increased salt tolerance in yeast (Lippuner, et al., 1996), it was of interest to determine if the corresponding 
gene was induced in plants exposed to elevated levels of salt. Reverse transcriptase (RT)-PCR was analysed with RNA isolated from control and $\mathrm{NaCl}$-treated Arabidopsis plants at 100, 200, and $400 \mathrm{mM}$ of $\mathrm{NaCl}$ (Fig4 A). A constant level of loading control (rRNA) was observed in presence of $\mathrm{NaCl}$ and $(0)$ control (without $\mathrm{NaCl}$ ). In contrast, the levels of expression of AtSTO were low in zero $\mathrm{mM} \mathrm{NaCl}$-treated plants and increased approximately 2folds in the presence of 100 and $200 \mathrm{mM}$ of $\mathrm{NaCl}$. At the highest $\mathrm{NaCl}$ concentration $(400 \mathrm{mM})$ the AtSTO mRNA levels were 4-fold higher than in the zero $\mathrm{mM} \mathrm{NaCl}$. The results showed a significant increase of the transcript abundance under all of $\mathrm{NaCl}$ conditions tested but it could not be named AtSTO as a gene induced by $\mathrm{NaCl}$. So an additional experiment was performed to analyse the level of expression of AtSTO in presence of $\mathrm{NaCl}$ at 0 and $400 \mathrm{mM}$ concentration but with different amounts of total RNA, $(0,50$, $100,200 \mathrm{ng}$ of RNA in order to be sure that the AtSTO expression not affected by error of RNA amounts. Total RNA was extracted from plants exposure at $\mathrm{NaCl} 0$, and $400 \mathrm{mM} \mathrm{NaCl}$ and AtSTO gene expression was obtained by RT-PCR, (Fig4 B). A similar expression level of AtSTO was clearly observed under these conditions, measured as being approximately 8fold higher in plants treated with $400 \mathrm{mM} \mathrm{NaCl}$ to plants treated with zero $\mathrm{mM}$ $\mathrm{NaCl}$ (Fig4 B) especially when compared with 200ng of RNA. These results suggest that AtSTO expression is salt regulated and appear to respond to $\mathrm{NaCl}$ in the medium and seems to respond differentially at any given salt concentration.

\section{Expression of AtSTO in PEG-treated plants.}

Drought stress is the most common adverse environmental condition that can seriously reduce crop productivity. Increasing crop resistance to drought stress would be the most economical approach to improve agricultural productivity and to reduce agricultural use of fresh water resources.

The biological basis for drought tolerance is still largely unknown and few drought tolerance determinants have been identified (Ludlow and Muchow, 1990; Bruce et al., 2002). Despite the lack of understanding of drought tolerance mechanisms, physiological and molecular biological studies have documented several plant responses to drought stress (Bohnert et al., 1995; Blum 1996; Luan, 2002). The products of certain stress-responsive genes could function in alleviating stress damage through still unclear mechanisms (Hasegawa et al., 2000). The first identification of ATSTO was done by (Lippuner, et al 1996), as a salt-responsive gene and (Indorf, et al 2007) has identified ATSTO as a light signalling gene. Reverse transcriptase (RT)-PCR was analysed with RNA isolated from control and PEG-treated Arabidopsi plants at $20 \%$ of PEG (Fig5 A). A constant level of loading control (rRNA) was observed in presence of PEG and (0) control without PEG. The levels of expression of AtSTO were low in zero mM PEG-treated plants and increased approximately 2 to 3 -fold in the presence of $20 \%$ of PEG. In order to confirm the above mentioned data we performed an additional experiment to analyse the level of expression of AtSTO in presence of PEG at 0 and $20 \%$ PEG but with different amounts of total RNA, $(0,50,100,200 \mathrm{ng}$ of RNA in order to be sure that the AtSTO expression not effected by error of RNA amounts. Total RNA was extracted from plants exposure at PEG (0, and PEG 20\%) and 


\section{EI-Shami, M. I. et al.}

AtSTO gene expression was obtained by RT-PCR, (Fig4 B). A similar expression level of AtSTO was clearly observed under these conditions, measured as being approximately 8 to 10 fold higher in plants treated with PEG 20\% as compared to plants treated with zero PEG (Fig4 B) especially when comparing with 200ng of RNA. The obtained data suggest that AtSTO is drought response and linked to drought tolerance and may define a novel pathway controlling plant drought tolerance.

Figures:-
ATST

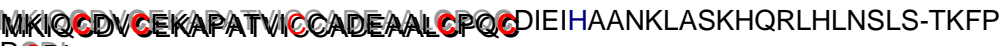 $\mathrm{R} C \mathrm{D}$ il
OSSTO MARIQDACACA EATIVICOADEAALCARODVEIHAANKLASKHQRLPLDAAL PAAL PRCDV
GMSTO MUKIQCDVCEIKAPAATVIICGADEAALCAKCDVEVHAANKLASKHQRLLLQSVS-NKL PRCDil
SSSTO MHIQCDVCEIKAQATVIICADEEALCAKCDIEVHAANKLASKHQRLHLQCLS- NKLP $P C D \|$
ZMSTO MIKIQCDACEGAAATVVCADEAALCARIODVEIHAANKLASKHQRLPLEALS -AKLP RCDV
ATSTO
CQEEKAAAFIFCVEDRAALLCRDODESIHVANSRSANHQRFLATGIKVALT $-S T I$

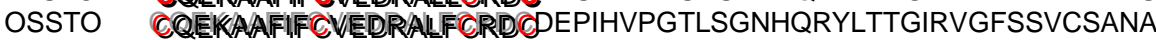 DHLPP

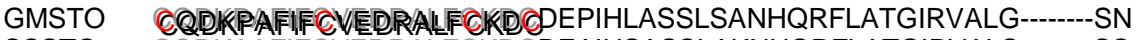
SSSTO CQDIKAAFIIFCVEDRALILCKDEDEAIHSASSLAKNHQRFLATGIRVALS-------SS

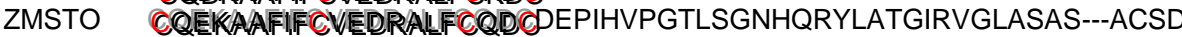
ATSTO CSKEIEKNQPEPSNNQQKANQIPAKSTSQQQQQPSSATPLPWAVDDFFHFSD IES TDK-K
OSSTO PAPKGNSKPPASGIAAAAAPKPAVSAAAQEVPSSPFLPPSGWAVEDLLQLSDY ESSD-K
GMSTO CTKGNEKGHVEPS--KPKAQEVPAKIPSQQVPSFTSS----WAVDDLLELTDFESPD K-V
SSSTO CNKEAVKNQLEPQPPQQNSQQVGLKMPPQQLSGITSPS-WPVDDLL GFPD YE SSDK-K
ZMSTO ACDAHDSDHHAPPKATIEPPHAAVSAAVQQVPSPPQFLPQGWAVDELLQFSD YESSD KLH
ATSTO GQLDLGAGELDWFSDMGFFGDQINDKAL-PAAEVPELSVSHL------GHVHSYK PMKSN
OSSTO KGSPIGFKDLEWLDDIDLFHVQSPAKGGSTAAEVPELFASPQP-------ASNMGLYKAS
GMSTO QKQSLEFGELEWLADVGLFGEQFPHEAL-AAAEVPQLPMTSS----VGSHKAPKSL
SSSTO D--LLELGEFEWLGGIDLFGEQT-------AAEVPELSVPQS------SNTNIYKTTKYQ
ZMSTO KEPTLGFKELEWFADIDLFHEQAPKASRTLAEVPELFGYQAANDAAYYRPAK AAGGGGA
ATSTO VSHKKPRFETRYDDDDEEHFIVPDLG
OSSTO GARQSKKPRVEIPDDDEDFFIVPDLG
GMSTO LSYKKPRIEVLDEDDDE-HFTVPDLG
SSSTO MPYKKPRIEISDEDE---YFTVPDLG
ZMSTO GVRQSKKARIEVTDD-EDYLIVPDLG

Figure (1):Alignment of Amino acid sequences of STO cDNAs, clones encoding putative zinc finger proteins of Arabidopsis (ATSTO) AC 024174, Oryza sativa (OSSTO) AC NM 001063369, Glycine max (GMSTO) AC ABB29467, Solanum sogarandinum (SSSTO AC ABC25454 and Zea mays (ZMSTO) AC ACG41790. The Structure of STO sequences protein of crops revealed that two cysteine cores in each finger were interrupted by 23 or 24 amino acid residues with a consensus sequence of "Cys-X2-Cys-X8Cys-X6-Cys-X2- Cys. 
STO

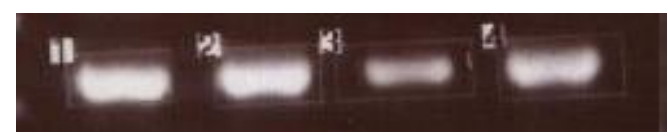

rRNA

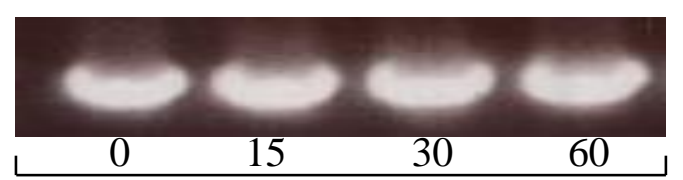

Min from incubation

Figure (2): $\mathrm{H}_{2} \mathrm{O}_{2}$ affects AtSTO gene expression. RT-PCR was obtained from $(0,15,30$ and 60 minutes from incubated Arabidopsis plants in presence of $1 \mathrm{mM} \mathrm{H}_{2} \mathrm{O}_{2}$.

ST

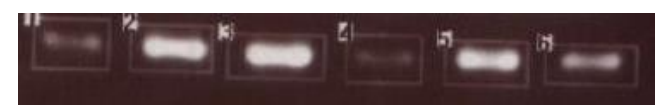

rRN

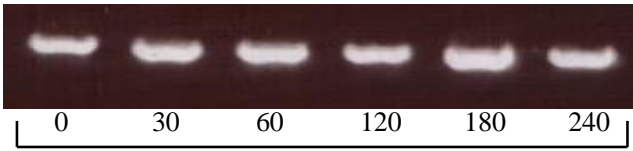

Minutes after adding BFA.

Figure (3): Expression in presence of BFA at $1 \mathrm{mM}$ concentration for 0 , $30,60,120,180$ and 240 minutes from incubation 
EI-Shami, M. I. et al.

(A)

STO
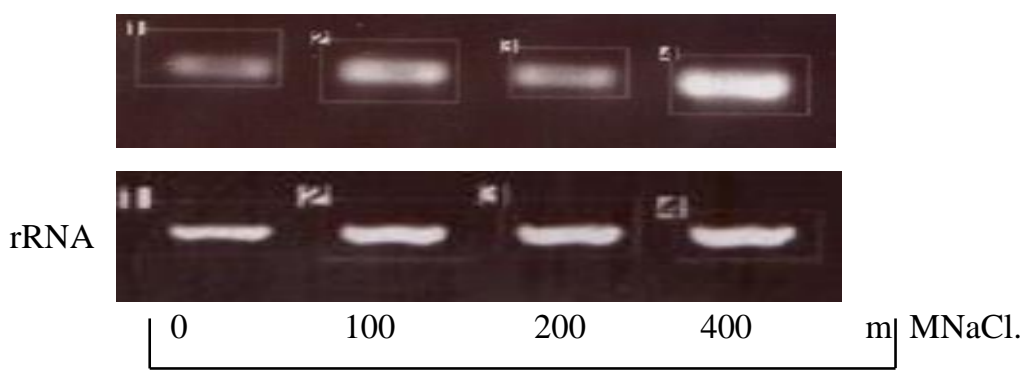

(B

ST

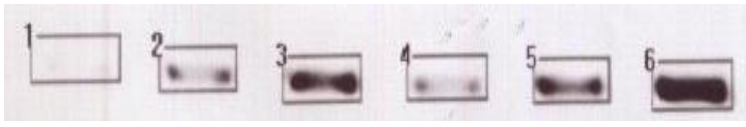

rRN

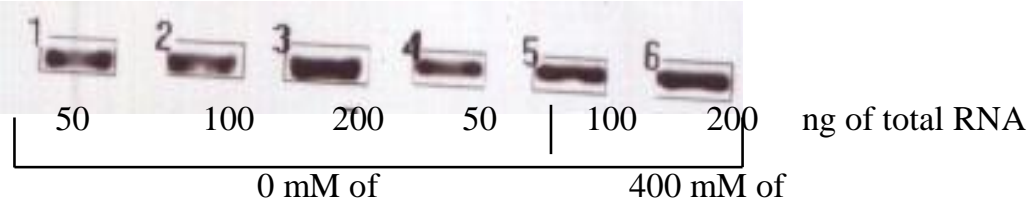

Figure (4): Expression of AtSTO in NaCl-treated plants.

(A) AtSTO expression in presence of $\mathrm{NaCl}$ at $0,100,200$, and $400 \mathrm{mM}$ concentration. Total RNA was extracted from plants after $24 \mathrm{~h}$ of exposure to $\mathrm{NaCl}$ and AtSTO gene expression was obtained by RT-PCR and equal loading was confirmed by rRNA in all lanes.

(B) AtSTO expression in presence of $\mathrm{NaCl}$ at 0 and $400 \mathrm{mM}$ concentration. Total RNA was extracted from plants after $24 \mathrm{~h}$ of exposure to $\mathrm{NaCl}$ and AtSTO gene expression was obtained by RT-PCR with different amounts of total RNA, $(0,50,100,200 \mathrm{ng}$ of RNA. 
(A)

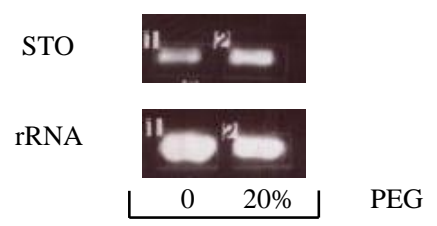

(B)

STO

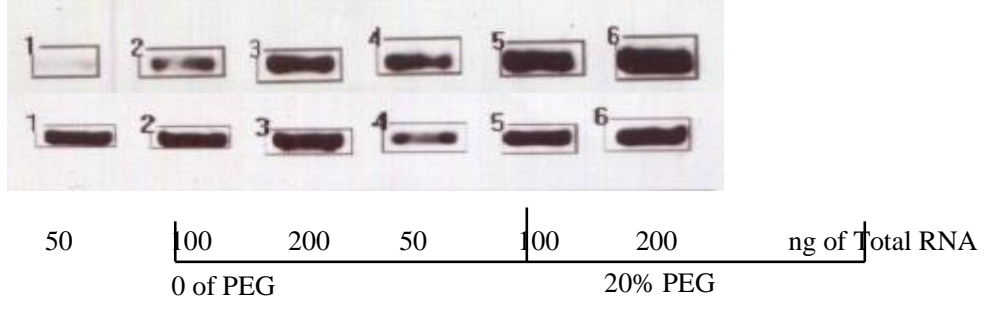

Figure (5): Expression of AtSTO in PEG 20\% treated plants.

(A) AtSTO expression in presence of PEG $20 \%$ concentration. Total RNA was extracted from plants after $24 \mathrm{~h}$ of exposure to PEG at $20 \%$ and STO gene expression was obtained by RT-PCR.

(B) AtSTO expression in presence of PEG at0 and 20\%. Total RNA was extracted from plants after $24 \mathrm{~h}$ of exposure to PEG at $20 \%$ and STO gene expression was obtained by RT-PCR with different amounts of total RNA, (0, 50, 100, $200 \mathrm{ng}$ of RNA.

\section{REFERENCES}

Adler, V.; Schaffer, A.; Kim, J.; Dolan, L. and Ronai, Z. 1995. UV irradiation and heat shock mediate JNK activation via alternate pathways. Journal of Biological Chemistry. 270, 27071-26077.

Adler, V.; Yin, Z.; Tew. K.D. and Ronai Z. 1999. Role of redox potential and reactive oxygen species in stress signaling. Oncogene, 18, 6104-6111.

Ausubel, E.M; Breent, R.; Kingston, R.; Moor,D; Seidman, J.G; Smith, J.A and Strihl, K. 1998. New york Greene Publishing/Wiley Interscience,.

Belles-Boix, E., Babiychuk, E., Van Montagu, M., Inze, D. and Kushnir, S. 2000. CEO1, a new protein from Arabidopsis thaliana, protects yeast against oxidative damage. FEBS Lett., 482, 19-24.

Blum, A. 1996. Crop responses to drought and the interpretation of adaptation. J. Plant Growth Regul., 20: 135-148

Bohnert, H. J.; Nelson, D.E. and Jensen, R.G. 1995. Adaptations to environmental stresses. Plant Cell, 7: 1099-1111

Bruce, W.B.; Edmeades, G.O. and Barker, TC. 2002.Molecular and physiological approaches to maize improvement for drought tolerance. J. Exp. Bot., 53: 13- 22

Cushman, JC; Bohnert, HJ. 2000. Genomic approaches to plant stress tolerance. Curr Opin Plant Biol. 3(2):117-24. 


\section{EI-Shami, M. I. et al.}

Desikan R, Mackerness A-H S, Hancock JT, Neill SJ. 2001. Regulation of the Arabidopsis transcriptome by oxidative stress. Plant Physiol. 127(1):159-72.

Fujibe, T., Saji, H., Arakawa, K., Yabe, N., Takeuchi, Y. and Yamamoto, K.T. 2004. A methyl viologen-resistant mutant of Arabidopsis, which is allelic to ozone-sensitive rcd1, is tolerant to supplemental ultraviolet-B irradiation. Plant Physiol, 134, 275-285.

Geldner, N., Anders, N., Wolters, H., Keicher, J., Kornberger, W., Muller, P., Delbarre, A., Ueda, T., Nakano, A., and Jurgens, G. 2003. The Arabidopsis GNOM ARF-GEF mediates endosomal recycling, auxin transport, and auxin-dependent plant growth. Plant Cell, 112: 219-230.

Geldner, N., Friml, J., Stierhof, Y.D., Jurgens, G., and Palme, K. 2001. Auxin transport inhibitors block PIN1 cycling and vesicle trafficking. Nature. 413: 425-428.

Griffiths, S., Dunford, R.P., Coupland, G. and Laurie, D.A. .2003. The evolution of CONSTANS-like gene families in barley, rice, and Arabidopsis. Plant Physiol,131, 1855-1867.

Guan, L.; Zhao, J. and Scandalios, J.G. 2000. Cis-elements and transfactors that regulate expression of the maize CAT1 antioxidant gene in response to $A B A$ and osmotic stress: $\mathrm{H}_{2} \mathrm{O}_{2}$ is the likely intermediary signaling molecule for the response. The Plant Journal, 22, 87-95.

Hasegawa, PM.; Bressan, RA.; Zhu, JK and Bohnert, HJ. 2000. Plant cellular and molecular responses to high salinity. Ann. Rev. plant physiol. 51: 463-499

Holm, M., Hardtke, C.S., Gaudet, R. and Deng, X.W. 2001. Identification of a structural motif that confers specific interaction with the WD40 repeat domain of Arabidopsis COP1. EMBO J., 20, 118-127.

Indorf Martin, Julio Cordero, Gunther Neuhaus, and Marta Rodri'guezFranco.2007. Salt tolerance (STO), a stress-related protein, has a major role in light signalling. The Plant Journal. 51, 563-574

Jose' C. Reyes, M. Isabel Muro-Pastor, and Francisco J. Florencio. 2004. The GATA Family of Transcription Factors in Arabidopsis and Rice1. Plant Physiol. Vol. 134, 1718-32

Jianyu SONG, Kimiko YAMAMOTO, Ayahiko SHOMURA, Hiraku TADANI, Hui Sun ZHONG, Masahiro YANO, and Takuji SASAKI.1998. Isolation and Mapping of a Family of Putative Zinc-finger Protein cDNAs from Rice. DNA RESEARCH 5, 95-101

Kamata $\mathrm{H}$, and Hirata $\mathrm{H}$. 1999. Redox regulation of cellular signalling. Cellular Signalling 11, 1-14

Katiyar-Agarwal, S., Zhu, J., Kim, K., Agarwal, M., Fu, X., Huang, A. and Zhu, J. K. 2006. The plasma membrane $\mathrm{Na}+\mathrm{H}+$ antiporter SOS1 interacts with RCD1 and functions in oxidative stress tolerance in Arabidopsis. Proc. Natl Acad. Sci. 103, 18816-18821.

Lagercrantz, U. and Axelsson, T. 2000. Rapid evolution of the family of CONSTANS LIKE genes in plants. Mol. Biol. Evol. 17, 1499-1507.

Lippuner, V., Cyert, M.S. and Gasser, C.S.1996. Two classes of plant CDNA clones differentially complement yeast calcineurin mutants and increase salt tolerance of wild-type yeast. J. Biol. Chem. 271, 1285912866.

Luan S. 2002. Signaling drought in guard cells. Plant Cell Environ. 25: 229237

Ludlow MM, Muchow RC.1990. A critical evaluation of trait improving crop yields under water-limited environments. Adv Agron 43: 107-153. 
Ma, L., Gao, Y., Qu, L., Chen, Z., Li, J., Zhao, H. and Deng, X.D. 2002. Genomic evidence for COP1 as a repressor of light-regulated gene expression and development in Arabidopsis. Plant Cell, 14, 23832398.

Mount, DW. 1996. Reprogramming transcription. Nature. 383, 763-764.

Nebenfuhr, A., Ritzenthaler, C., and Robinson, D.G. 2002. Brefeldin A: Deciphering an enigmatic inhibitor of secretion. Plant Physiol. 130:1102-1108.

Neill SJ, Desikan R, Clarke A, Hurst RD, Hancock JT. 2002. Hydrogen peroxide and nitric oxide as signaling molecules in plants. Journal of Experimental Botany. 53, 1237-1247.

Putterill, J., Robson, F., Lee, K., Simon, R. and Coupland, G. 1995. The CONSTANS gene of Arabidopsis promotes flowering and encodes a protein showing similarities to zinc finger transcription factors. Cell, 80 , 847-857.

Rhee SG. 1999. Redox signaling: hydrogen peroxide as intracellular messenger. Experimental and Molecular Medicine 31, 53-59.

Teakle GR, Manfield IW, Graham JF, Gilmartin PM. 2002. Arabidopsis thaliana GATA factors: organisation, expression and DNA-binding characteristics. Plant Mol Biol. Sep; 50 (1):43-57.

Yu Xing.I, Wensuo Jia, and Jianhua Zhang. 2007. AtMEK1 mediates stressinduced gene expression of CAT 1 catalase by triggering $\mathrm{H} 2 \mathrm{O} 2$ production in Arabidopsis. Journal of Experimental Botany, Vol. 58, No. 11, pp. 2969-2981,

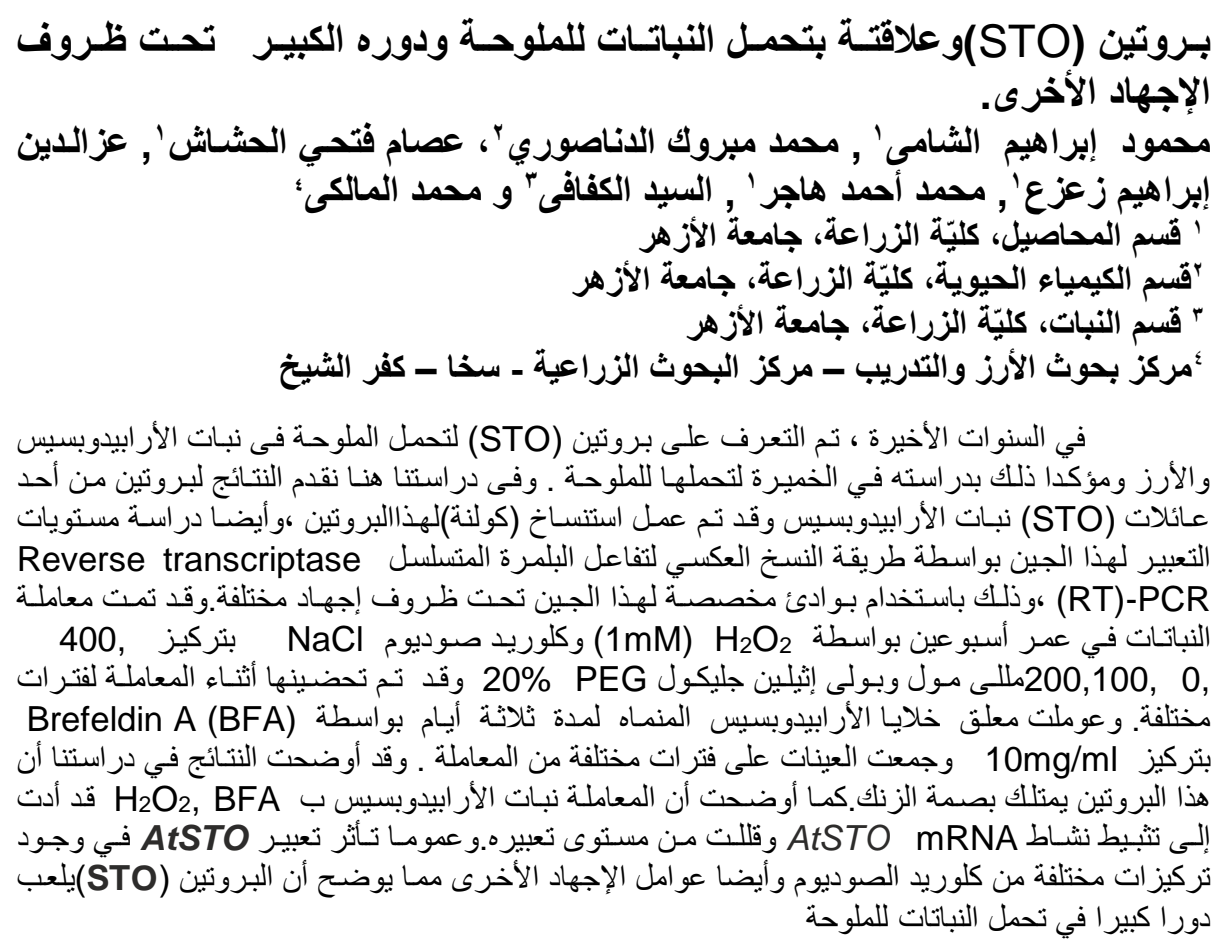

